\title{
Aplikasi Pengunaan Visual Basic Pada Perhitungan Indeks Keandaan Pembangkit
}

\author{
Adri Senen ${ }^{*}$, Zulfikar Rizqi Akbar $\mathrm{P}^{2}$ \\ 1,2 Jurusan Teknik Elektro, Sekolah Tinggi Teknik PLN \\ *Corresponding Author, Ad_Senen@yahoo.com
}

\begin{abstract}
Abstrak- Indeks keandaan pembangkit adalah suatu kemungkinan bahwa sistem tidak dapat melayani beban atau kebutuhan pelanggan tenaga listrik yang dapat dinyatakan juga sebagai indeks probabilitas kehilangan beban (loss of load probability, LOLP). Perhitungan LOLP diharapkan dapat menggambarkan nilai besar kecil nya peluang terjadi nya kehilangan beban sebagai akibat kurang nya daya yang tersedia dalam sistem. Kemungkinan energi tak terpenuhi (Expected Energy Not Served, EENS) dalam sistem terjadi karena gangguan unit pembangkit yang menyangkut besar daya dan lama kekurangan energi. Oleh karena itu perhitungan yang teliti dan akurat untuk mendapatkan nilai LOLP yang tepat menjadi suatu keniscayaan dalam menentukan indeks keandalan pembangkit. Proses perhitungan yang rumit dan panjang cendrung memeberikan hasil yang kurang tepat kalau dihitung secara manual. Berdasarkan hal tersebut untuk mempermudah dalam prose perhitungan keandalan pembangkit maka perlu dirancang sebuah aplikasi yang dapat menyelesaikan hal tersebut. Visual Basic menjadi salah satu solusi dari penyelesaian masalah ini. Visual Basic merupakan turunan bahasa pemrograman BASIC dan menawarkan pengembangan perangkat lunak komputer berbasis grafik dengan cepat. Hasil rancangan aplikasi bisa meghitung hingga 7 (tujuh) pembangkit, tergantung dari jumlah pembngkit yang tersedia.
\end{abstract}

Keywords: Keandalan, LOLP, Visual Basic, Pembangkit.

Abstract- The index's generator reliability index is a possibility that the system cannot serve the load or the needs of electric power customers which can be expressed as a loss of load probability (LOLP) index. LOLP calculation is expected to be able to illustrate the value of the chance of loss due to lack of available power in the system. The possibility of unfulfilled energy (Expected Energy Not Served, EENS) in the system occurs due to disruption of the generating unit which involves a large amount of power and a long time of lack of energy. Therefore, calculation has to be done carefully and accurately to get the value of LOLP becomes a necessity in determining the reliability index of the plant. The calculation process is complicated and long tends to give results that are less precise if calculated manually. Based on this to make it easier to calculate the reliability of the generator, it is necessary to design an application that can resolve this. Visual Basic is one of the solutions to solving this problem. Visual Basic is a derivative of the BASIC programming language and offers graphics-based computer software development quickly. The results of the application design can count up to 7 (seven) generators, depending on the number of developers available

Keywords: Realiability, LOLP, Visual Basic, Generator.

(C) 2019 Elektron Jurnal Ilmiah

\section{I.PENDAHULUAN}

Keandalan sistem tenaga listrik dalam menyalurkan tenaga listrik merupakan probabilitas suatu peralatan atau komponen listrik untuk mampu melakukan operasi pada waktu tertentu dan dalam kondisi operasi tertentu pula. Sehingga dapat melayani kebutuhan tenaga listrik bagi konsumen. Guna mencapai keandalan tenaga listrik yang maksimal memerlukan adanya evaluasi dan pengembangan pembangkit. Kemungkinan bahwa sistem tidak dapat melayani beban atau kebutuhan pelanggan tenaga listrik dinyatakan dengan indeks probabilitas kehilangan beban (loss of load probability, LOLP). LOLP menggambarkan besar kecil nya peluang terhadap terjadi nya kehilangan beban sebagai akibat kurang nya daya yang tersedia dalam sistem. Kemungkinan energi tak terpenuhi (Expected Energy Not Served, EENS) dalam sistem terjadi karena gangguan unit pembangkit yang menyangkut besar daya dan lama kekurangan energi.
Pengembangan pembangkit yang lambat menyebabkan pemadaman atau pemutusan dalam penyediaan tenaga listrik bagi konsumen sebagai akibat terjadinya beban yang lebih besar daripada kapasitas pembangkit. Pertambahan beban yang tidak diimbangi dengan penambahan daya pada pusat pembangkit, mengakibatkan keandalan pembangkit berkurang dan nilai energi tak terpenuhi pada beban akan meningkat. Tingkat keandalan pembangkit dihitung dengan nilai indeks LOLP (Loss of Load Probability), EENS (Expected Energy Not Served), dan faktor keandalan pembangkit. Semakin kecil nilai LOLP dan EENS pembangkit, maka tingkat keandalan pembangkit semakin baik

Secara umum perhitungan keandalan dilakukan secara manual untuk pembangkit pembangkit yang jumlahnya terbatas. Hal ini mengakibatkan akan memakan waktu yang lama jika sekiranya dilakukan evaluasi terhadap kinerja pembangkit, karena perhitungang yang dilakukan menggunakan iterasi dan proses hitung yang cukup rumit karena Indeks LOLP dapat memberikan analisis 
secara statistik dengan menghitung peluang beroperasinya pembangkit. Karena rumit nya perhitungan dan perlu nya hasil dengan cepat maka penulis akan membuat aplikasi perhitungan LOLP dan juga perhitungan EENS dengan menggunakan program visual basic 6.0, karena visual basic 6.0 merupakan bahasa mesin tingkat tinggi yang paling mudah dimengerti oleh manusia pada umum nya. Para pengguna hanya perlu memasukan nilai dari data kapasitas pembangkit dan besar nya F.O.R (Forced Outage Rate).

Hasil program dari penelitian ini nantinya bisa digunakan untk mengitung dengan cepat keandalan pembangkit. Perhitungan dilakukan dengan hanya memasukkan parameter saja dan tinggal run maka hasil LOLP akan didapat tanpa harus melakukan iterasai dan perulangan yang rumit. Disamping itu aplikasi ini bisa sekaligus mengitung besarnya EENS dari pembangkit itu sendiri

Aplikasi menggunakan perhitungan Visual Basic 6.0 berdasarkan metode LOLP dan EENS yang digunakan dalam menghitung keandalan pembangkit tenaga listrik agar lebih mudah dalam melakukan perhitungan. Diharapkan dapat menjadi bahan pertimbangan dalam pengembangan penelitian terkait perhitungan LOLP dan EENS dan juga diharapkan dapat menjadi refrensi penggunaan Visual Basic 6.0 dalam pengolahan data dalam bidang ketenagalistrikan.

\section{METODE}

\section{A. Analisa Kebutuhan}

Untuk mendapatkan perumusan, analisa dan penyelesaian masalah maka dibutuhkan pengumpulan data dan fakta yang lengkap, relevan dan objektif serta dapat dipercaya kebenarannya. Maka dari itu, proses pengumpulan data, lalu menganalisa studi kasus dan menyusun laporan penelitian dengan menggunakan metode studi literatur, studi Pustaka dan konsultasi

\section{B. Perancangan Penelitian}

Berikut ini menjelaskan langkah-langkah yang akan dilakukan dalam penyusunan skripsi. Untuk memahami setiap tahapan penulisan yang ada, akan diberikan penjelasan sebagai berikut :

1. Pendahuluan

Pendahuluan adalah langkah awal metodologi penulisan. Informasi awal sangat penting dalam memulai tahap penulisan sehingga diharapkan mampu memahami persoalan.

2. Identifikasi dan Perumusan Masalah

Setelah dilakukan pendahuluan, maka akan didapat permasalahan yang bisa ditelusuri. Dengan memahami permasalahan yang ada, maka akan dibuat perumusan masalah untuk menyelesaikan masalah secara bertahap. Dalam menentukan permasalahan. Permasalahan yang akan dibahas dalam adalah Perancangan aplikasi perhitungan keandalan pembangkit dengan menggunakan program visual basic 6.0

3. Studi Pustaka

Studi pustaka dilaksanakan untuk mendapatkan informasi berupa berbagai macam teori mengenai permasalahan yang dibahas. Studi pustaka dilakukan untuk mendapatkan informasi dan referensi berbentuk text book, ataupun sumber karya tulis lainnya.

4. Pengumpulan Data

Pengumpulan data dilakukan dengan membaca literatur-literatur serta beberapa karya ilmiah yang terkait dengan data yang diperlukan. Dapat pula dilakukan dengan mengamati berkasberkas data yang dimiliki oleh perusahaan untuk mempermudah jalannya penelitian. Data yang diperlukan diantaranya adalah:

a. Data besar daya pembangkit

b. Data besar f.o.r pembangkit

c. Data besarnya beban pada pembangkit

d. Software Visual Basic 6.0

\section{Pengolahan data}

Pengolahan data dilaksanakan setelah semua kebutuhan data terpenuhi. Pengolahan data dilakukan dengan melakukan perhitungan yang diantaranya:

a. Perhitungan rata-rata beban perhari dan perjam dalam 1 bulan ( bulan juli 2018)

b. Perhitungan grafik beban selama 1 bulan serta grafik lama beban dalam 1 bulan.

6. Perancangan Program

Apabila perhitungan jumlah rata-rata beban dalam 1 bulan serta grafik rata-rata beban dan grafik lama beban dalam kurun waktu 24 jam dengan rata-rata 1 bulan. Setelah itu hasil yang didapatkan dimasukan kedalam program guna melengkapi pembuatan program, selanjutnya adalah mengevaluasi program dan memperbaiki error yang terjadi serta mengkoding ulang jika terjadi tumpang tindih printah dalam program tersebut. Diharapkan perhitungan dengan menggunakan program Visual Basic 6.0 didapatkan hasil yang sesuai dengan perhitungan manualnya.

\section{HASIL DAN PEMBAHASAN}

\section{A. Pembangkit}

PT. PLN (Persero) PLTU Lontar memiliki 3 unit pembangkit dengan masing-masing pembangkit memiliki daya maksimal sebesar 315 MW. Pembangkit Unit1 memiliki nilai FOR sebesar 0,03 sedangkan Unit 2 memiliki nilai FOR Sebesar 0,032 dan Unit 3 memiliki nilai FOR sebesar 0,018. Data tersebut dapat dilihat ditabel dibawah ini : 
Tabel 1. Data Daya Pembangkit

\begin{tabular}{ccc}
\hline Pembangkit & Daya & FOR \\
\hline UNIT 1 & 315 & 0.03 \\
& MW & \\
\hline UNIT 2 & 315 & 0.032 \\
& MW & \\
\hline UNIT 3 & 315 & 0.018 \\
& MW & \\
\hline
\end{tabular}

Table 2. Data FOR \& IR Pembangkit Standar PLN

\begin{tabular}{ccc}
\hline Pembangkit & FOR Standar PLN & Intage Rate \\
\hline UNIT 1 & 0.085 & 0.915 \\
\hline UNIT 2 & 0.085 & 0.915 \\
\hline UNIT 3 & 0.085 & 0.915 \\
\hline
\end{tabular}

\section{B. Data Beban}

Data beban yang tercatat selama tahun 2018 akan dijadikan sebagai dasar mencari pola beban maupun sebagai dasar perhitungan faktor-faktor yang menentukan indeks keandalan seperti Faktor Beban, Faktor Ketersediaan, LOLP (Loss Of Load Probability) maupun EENS (Expected Energy Not Serverd). Data yang akan diambil adalah data pada bulan Juli 2018 karena memiliki rata-rata beban terbesar selama tahun 2018. Pada data dibawah ini adalah contoh data dimana beban tertinggi terjadi selama bulan Juli 2018 yaitu sebesar 859 MW.

\section{Pola Beban}

Pola beban dapat menggambarkan bagaimana kebutuhan beban sistem pada periode tertentu yang sedang diamati. Menurut periode waktunya terbagi menjadi pola beban harian dan pola beban mingguan.

\section{Perhitungan Data Beban}

Dari tabel data beban yang telah diperoleh dapat dilakukan perhitungan faktor-faktor yang menentukan keandalan pembangkit. Untuk perhitungan faktor beban maka dapat diketahui dengan menggunakan rumus sebagai berikut:

$$
\begin{aligned}
& \text { Faktor Beban }=\frac{\text { Produksi Energi }(\mathrm{MWh})}{\text { Beban Puncak } * \text { Total jam }} \\
& \text { Faktor Beban }=\frac{579012.5}{859 * 744} \times 100 \% \\
& =90.59867375 \%
\end{aligned}
$$

Bagi penyedia tenaga listrik, faktor beban harus setinggi mungkin $(100 \%)$, hal ini disebabkan karena faktor beban yang semakin tinggi (100\%) berarti semakin rata beban sistem. Walaupun Standar PLN, faktor beban tahunan berkisar antara 60\%-80\%, dapat dilihat dari hasil perhtiungan diatas bawah faktor beban mencapai $90.6 \%$ yang berarti hasil tersebut sudah diatas dari standar yang dibuat oleh PLN.

Untuk menghitung faktor ketersediaan dapat digunakan rumus sebagai berikut:

$$
\begin{aligned}
\text { Faktor Ketersediaan }= & \frac{\text { Daya } \text { Tersedia }}{\text { Daya } \text { Terpasang }} \\
\text { Faktor Ketersediaan }=\frac{840}{945} \times & 100 \% \\
& =88.9 \%
\end{aligned}
$$

Untuk menentukan faktor penggunaan dapat digunakan rumus sebagai berikut:

$$
\begin{gathered}
\text { Faktor Penggunaan }=\frac{\text { Beban } \text { Puncak }}{\text { Daya Terpasang }} \\
\begin{aligned}
\text { Faktor Penggunaan }=\frac{859}{945} \times 100 \% \\
=90.8 \%
\end{aligned}
\end{gathered}
$$

Dapat dilihat dari hasil perhitungan diatas bahwa faktor penggunaan sebesar $90.8 \%$, sistem pembangkit belum mengalami over loaded.

Untuk menentukan faktor kapasitas dapat digunakan rumus sebagai berikut:

$$
\begin{aligned}
C F & =\frac{\text { Produksi Energi }(M W h) \text { dalan satu Bulan }}{\text { Daya Mampu }(M W) \times 744 j a m} \\
C F & =\frac{579012.5(M W h)}{945(M W) \times 744 j a m} \\
& =82.4 \%
\end{aligned}
$$

Dapat dilihat bahwa hasil dari faktor kapasitas adalah sebesar $82.4 \%$, bahwa pembangkit yang bekerja pada bulan Juli mempunyai keandalan dalam memenuhi beban mencapai $82.4 \%$.

Untuk menentukan indeks LOLP (Loss Of Load Probability) dapat digunakan rumus sebagai berikut:

$$
L O L P=P x t
$$

Dimana:

$$
\begin{array}{ll}
\mathrm{P} \quad \text { = probabilitas terjadinya beban sama } \\
\text { atau lebih besar dari daya } \\
\text { yang tersedia } \\
\mathrm{t} \quad \text { waktu terjadinya kehilangan beban }
\end{array}
$$

Untuk menentukan indeks EENS (Expected Energy Not Served) dapat digunakan rumus sebagai berikut:

$E E N S=A n \times P n M W h$

Dimana :

An = Besarnya energi yang tidak dapat terpenuhi karena suatu gangguan.

Pn = Probabilitas sistem pembangkit tidak dapat mencukupikebutuhan beban.

\section{E. Loss Of Load Probability (LOLP)}

Pembangkit tidak selalu dapat beroperasi selama kurun waktu tertentu, seringkali karena mengalami kerusakan maupun terjadi pemeliharaan secara rutin. Jika pembangkit ini tidak beroperasi pada saat yang bersamaan atas beberapa unit, maka ada kemungkinan bahwa daya tersedia dalam sistem berkurang sedemikian besarnya sehingga tidak cukup untuk melayani beban. Ukuran sering tidaknya unit pembangkit mengalami gangguan dinyatakan dengan Forced Outage Rate (FOR), yaitu:

$$
\mathrm{FOR}=\frac{\mathrm{OH}}{\mathrm{SH}+\mathrm{OH}}
$$


Dimana:

OH : Outage Hours

SH : Service Hours

Tabel 3. Data FOR dan IR Pembangkit

\begin{tabular}{ccc}
\hline Pembangkit & FOR & Intage Rate \\
\hline Unit 1 & 0.03 & 0.97 \\
\hline Unit 2 & 0.032 & 0.968 \\
\hline Unit 3 & 0.018 & 0.982 \\
\hline
\end{tabular}

Dari tabel diatas, maka dapat disusun tabel vailability probability. Dengan delapan pembangkit yang memikul beban sistem maka didapatkan kombinasi :

Kombinasi $=2^{n} 2^{3} 8$

Dimana:

$\mathrm{n}=$ jumlah pembangkit

8 kombinasi kemungkinan pembangkit adalah sebagai berikut :

Unit yang diberi tanda selain 0 , yaitu unit yang beroperasi. Dan unit yang diberi tanda 0 , yaitu unit yang mengalami outage. Jumlah dari kemungkinan tersebut haruslah satu, sehingga dapat dipastikan semua kemungkinan delapan pembangkit dapat beroperasi atau tidak (outage).

Loss Of Load Probability (LOLP) adalah kemungkinan bahwa beban tidak seluruhnya dapat dipasok oleh pembangkit dalam sistem. Kemungkinan bahwa beban tidak dapat dipasok seluruhnya ini merupakan risiko yang dihadapi dalam sistem pembangkitan tenaga listrik sehingga perlu diformulasikan.

Tabel 4. Hasil LOLP Keseluruhan

\begin{tabular}{ccc}
\hline Kumulatif & $\begin{array}{c}\text { beban } \geq \\
\text { operasi } \\
\text { (jam) }\end{array}$ & LOLP \\
\hline 1 & 0 & 0 \\
\hline 0.07794128 & 744 & 57.98831232 \\
\hline 0.049424 & 744 & 36.771456 \\
\hline 0.01894272 & 744 & 14.09338368 \\
\hline 0.00204144 & 744 & 1.51883136 \\
\hline 0.00109872 & 744 & 0.81744768 \\
\hline 0.000576 & 744 & 0.428544 \\
\hline $1.728 \mathrm{E}-05$ & 744 & 0.01285632 \\
\hline & & 110.094597360001
\end{tabular}

Dari tabel 4. dapat dilihat bahwa hasil dari perhitungan keandalan pembangkit menggunakan metode LOLP adalah sebesar 111.6308314 jam. Jadi sistem pembangkit memiliki kemungkinan kehilangan beban sebesar 4.651284642 hari.
F. Simulasi Program

Simulasi 3 Unit Pembangkit

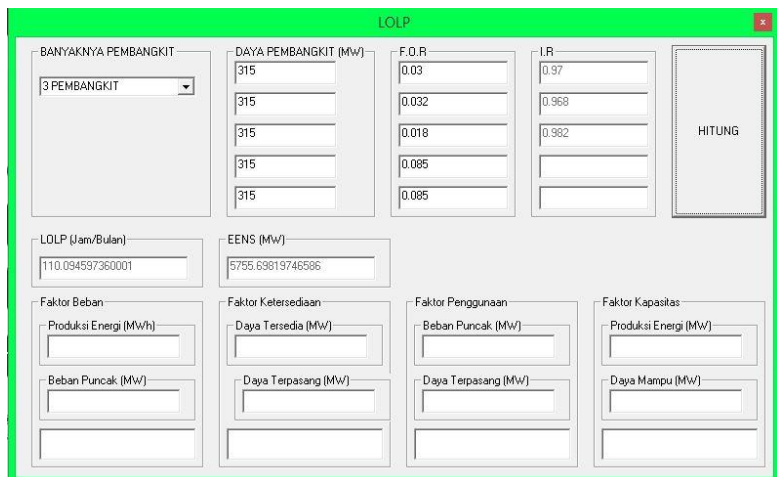

Gambar 1. Hasil LOLP 3 Unit Pembangkit

Dari gambar 1 dapat dilihat bahawa hasil perhitungan LOLP dengan menggunakan Program Perhitungan LOLP sama dengan perhitungan manual menggunakan Microsoft Excel. Walaupun memiliki hasil dan cara yang sama tetapi pada Program Perhitungan LOLP memiliki hasil yang lebih rincih dari hasil dengan menggunakan Microsoft Excel.

Simulasi 4 Unit Pembangkit

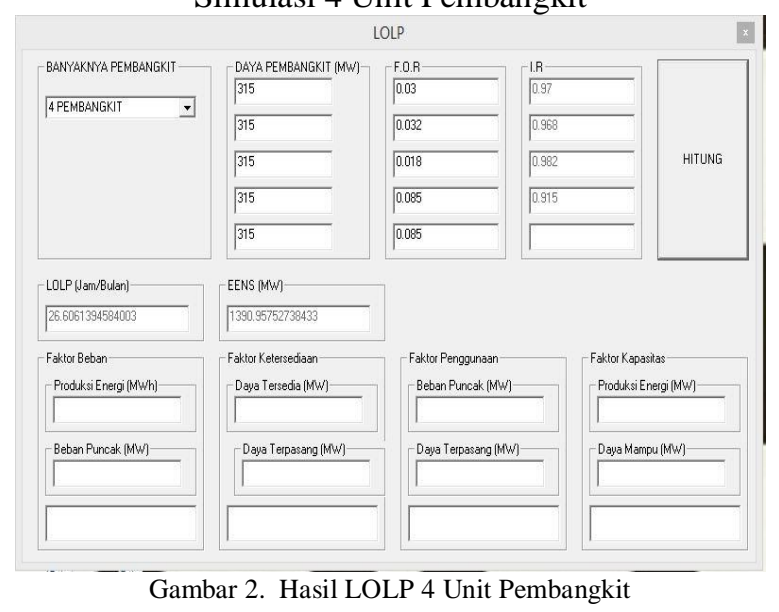

Dari gambar 2. dapat dilihat bahwa jika perhitungan menggunakan 4 Unit pembangkit dengan jumlah beban yang sama maka akan menghasilkan nilai LOLP yang lebih kecil dari pada menggunakan 3 Unit pembangkit. Dengan program VB 6.0 ini perhitungan dengan 4 Unit pembangkit hanya perlu mengganti pilihan "BANYAKNYA PEMBANGKIT" sehingga tidak perlu membuat perhitungan dari awal dengan 4 Unit pembangkit, sehingga perhitungan menjadi lebih cepat serta mendapatkan hasil yang lebih akurat karena menggunakan tipe data double yang mampu menghitung dari $10^{-37}$ sampai $10^{+38}$ digit angka sekaligus, dapat dilihat dari hasil perhitungan dengan 3 Unit pembangkit sebesar 110.094597360001 dan 4 Unit pembangkit sebesar 26.6061394584003. 
Simulasi 5 Unit Pembangkit

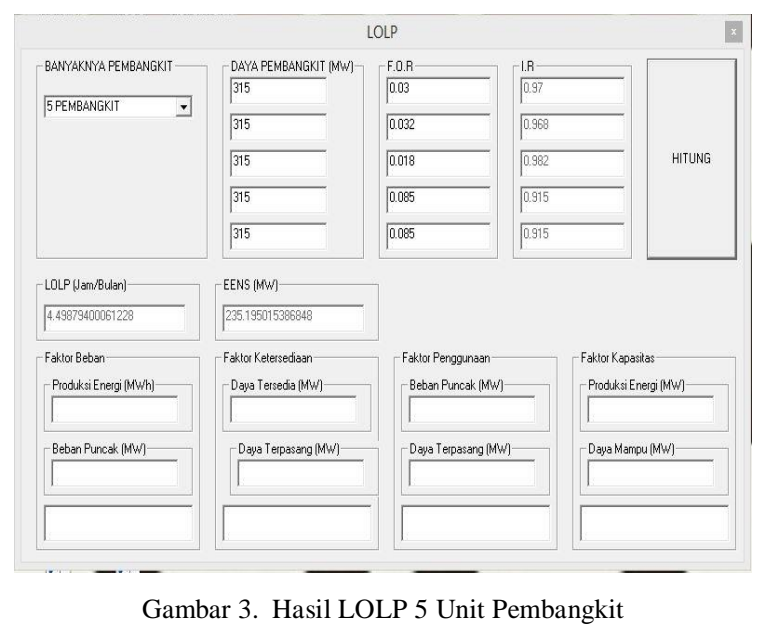

Dari gambar 3 dapat dilihat bahwa perhitungan dengan 5 Unit pembangkit memiliki hasil yang lebih kecil sebesar 4.49879400061228. Hasil tersebut lebih baik dari pada hasil pthitungan dengan 3 Unit pembangkit dan 4 Unit pembangkit yang masingmasing memiliki nilai sebesar 110.094597360001 untuk 3 Unit pembangkit dan 26.6061394584003 untuk 4 Unit pembangkit. Dengan program perhitungan LOLP yang dibuat menggunakan aplikasi VB 6.0 ini dapat terlihat banyak nya angka yang dapat dihitung sehingga akurasi ketelitian lebih baik serta kesalahan angka saat perhitungan menjadi berkurang karena banyak nya digit angka yang dapat dihitung dengan program tersebut.

Dengan hasil dari simulasi menggunakan 4 Unit pembangkit dan 5 Unit pembangkit dapat dilihat bahwa kecepatan dalam perhitungan dengan menggunakan program perhitungan LOLP tersebut menjadi lebih cepat dan hasil yang lebih akurat dari perhitungan manual biasa, bahkan lebih akurat dari kalkulator karena kalkulator memiliki maksimal dikit sebanyak 12 digit saja berbeda dengan program perhitungan LOLP ini yang dapat mencapai $10^{38}$ digit angka positif.

\section{H. Energy Expected Not Served (EENS)}

Tabel 5. Rata-rata Beban Bulan Juli 2018

\begin{tabular}{cccc}
\hline Jam & Total beban & Jam & Total Beban \\
\hline 00.30 & 775.7741935 & 12.30 & 762.6129032 \\
\hline 01.00 & 766.2903226 & 13.00 & 765.2903226 \\
\hline 01.30 & 756.5483871 & 13.30 & 780.1935484 \\
\hline 02.00 & 745.1290323 & 14.00 & 782.6774194 \\
\hline 02.30 & 752.3225806 & 14.30 & 780.7741935 \\
\hline 03.00 & 749.9032258 & 15.00 & 784.1935484 \\
\hline 03.30 & 745.6451613 & 15.30 & 782.0322581 \\
\hline 04.00 & 741.6774194 & 16.00 & 782.8387097 \\
\hline 04.30 & 741.6451613 & 16.30 & 779.8709677 \\
\hline
\end{tabular}

\begin{tabular}{rrrr}
\hline 05.00 & 749.6774194 & 17.00 & 783.9677419 \\
\hline 05.30 & 769.8387097 & 17.30 & 786.8387097 \\
\hline 06.00 & 772.3225806 & 18.00 & 796.7741935 \\
\hline 06.30 & 775.9032258 & 18.30 & 810.483871 \\
\hline 07.00 & 783.3870968 & 19.00 & 806.2903226 \\
\hline 07.30 & 776.8387097 & 19.30 & 805.2580645 \\
\hline 08.00 & 782.1612903 & 20.00 & 806.8064516 \\
\hline 08.30 & 786.2580645 & 20.30 & 806.9032258 \\
\hline 09.00 & 792.2580645 & 21.00 & 808.1935484 \\
\hline 09.30 & 790.8064516 & 21.30 & 807.2258065 \\
\hline 10.00 & 786.8709677 & 22.00 & 797.1935484 \\
\hline 10.30 & 767 & 22.30 & 795.6451613 \\
\hline 11.00 & 763.3870968 & 23.00 & 785.3225806 \\
\hline 11.30 & 753.3870968 & 23.30 & 785.9032258 \\
\hline 12.00 & 762.483871 & 24.00 & 784.8387097 \\
\hline
\end{tabular}

Tabel 6. Hasil Jumlah ENS

\begin{tabular}{rrr}
\hline $\begin{array}{r}\text { Beban } \\
(\mathrm{MW})\end{array}$ & \multicolumn{2}{c}{ ENS (MW) } \\
\hline 810 & 1 & 810 \\
\hline 808 & 1 & 808 \\
\hline 807 & 1 & 807 \\
\hline 806 & 3 & 2418 \\
\hline 805 & 1 & 805 \\
\hline 797 & 1 & 797 \\
\hline 796 & 1 & 796 \\
\hline 795 & 1 & 795 \\
\hline 792 & 1 & 792 \\
\hline 790 & 1 & 790 \\
\hline 786 & 3 & 2358 \\
\hline 785 & 2 & 1570 \\
\hline 784 & 2 & 1568 \\
\hline 783 & 2 & 1566 \\
\hline 783 & 2 & 1566 \\
\hline 782 & 4 & 3128 \\
\hline 780 & 2 & 1560 \\
\hline 779 & 1 & 779 \\
\hline 776 & 1 & 776 \\
\hline 775 & 2 & 1550 \\
\hline 772 & 1 & 772 \\
\hline 769 & 1 & 769 \\
\hline 767 & 1 & 767 \\
\hline & &
\end{tabular}




\begin{tabular}{rrr}
\hline 766 & 1 & 766 \\
\hline 765 & 1 & 765 \\
\hline 763 & 1 & 763 \\
\hline 762 & 2 & 1524 \\
\hline 756 & 1 & 756 \\
\hline 753 & 1 & 753 \\
\hline 752 & 1 & 752 \\
\hline 749 & 2 & 1498 \\
\hline 745 & 2 & 1490 \\
\hline 741 & 2 & 1482 \\
\hline Total ENS &
\end{tabular}

\section{KESIMPULAN}

Berdasarkan analisis selama melakukan perancangan dan hasil perhitungan dari Program Perhitungan LOLP dengan 3 sampai 5 pembangkit menggunakan program didapat dari 3 unit pembangkit dengan masing-masing pembangkit senilai $315 \mathrm{MW}$, didapatkan nilai LOLP dengan menggunakan program dinyatakan dalam 1 bulan (Bulan Juli) sebesar 110.095 jam/bulan, diketahui juga nilai EENS untuk 3 unit pembangkit yang dinyatakan dalam 1 bulan (Bulan Juli) sebesar 5527.762 MW/bulan. Hasil perhitungan dengan menggunakan 4 unit pembangkit sebesar 26.61 jam/bulan, dan dengan mensimulasikan menggunakan program didapat hasil perhitungan dengan menggunakan 5 unit pembangkit sebesar 4.5 jam/bulan.

Dengan adanya kemungkinan bahwa beban tidak dapat dipasok dalam kurun waktu tertentu akan berhubungan dengan jumlah energi yang tidak dapat dipenuhi juga oleh sistem pembangkit listrik tersebut, perkiraan energi yang tidak terpenuhi ini disebut juga Expected Energy Not Served. Perkiraan ini dapat dihitung dari hasil perhitungan LOLP dan perhitungan total kekurangan energi yang dibutuhkan untuk melayani keperluan beban ketika terdapat unit pembangkit mengalami outage atau biasa disebut ENS (Energy Not Served). Perhitungan ENS diambil dari load duration curve yang telah dikurangi oleh daya mampu pembangkit ketika mengalami outage. Data yang dibuat untuk menghitung EENS menggunakan data dari Kurva Lama Beban selama 1 bulan, dimana beban selama 1 bulan diambil rata-ratanya per 30 menit dan dijadikan Kurva Lama Beban.

$$
\begin{aligned}
& E E N S=\text { An } x \text { Pn MWh } \\
& E E N S=\frac{\text { Hasil LOLP Jam } / \text { Bulan }}{\text { Jumlah Jam }} \times E N S \\
& E E N S=\frac{110.094597360001}{744} \times 38896 \\
& \text { EENS }=5755.69819746586 \mathrm{MW}
\end{aligned}
$$

Hasil dari perhitungan EENS juga dapat dilihat pada Program Perhitungan LOLP yang telah dibuat. Hasil EENS yang didapat dengan Program Perhitungan LOLP untuk 3 Unit pembangkit adalah sebesar 5755.69819746586 MW. Hasil EENS dari simulasi juga dapat terlihat pada program yaitu untuk 4 Unit pembangkit adalah sebesar 1390.95752738433 MW dan untuk hasil EENS pada simulasi menggunakan 5 Unit pembangkit adalah sebesar 235.195015386848 MW.

\section{REFERENSI}

[1] Syahrial, K.Sawitri, P. Gemahhapsari, Studi Keandalan Ketersediaan Daya Pembangkit Listrik pada JaringanDaerah "X", Jurnal Elkomika, Vol.5, No.1, Hal 93-105, Juni 2017.

[2] Boroujeni, Hasan \& Eghtedari, Meysam \& Abdollahi Bastaki, Mostafa \& Behzadipour,. Calculation of generation system reliability index: Loss of Load Probability. Life Science Journal. 9. Elahe. (2012)

[3] A. Senen,T. Ratnasari, A Study of Biomass Power Plant Interconnection $1 \times 9.9 \mathrm{MW}$ in Deli Serdang, Journal of Applied Agricultural Science and Technology, Volume 3, Number 1, March, 3 (1): 41-50 (2019)

[4] Joko et al, "Pusat Pembangkitan Listrik", Penerbit Erlangga, Jakarta, 2013

[5] Djiteng Marsudi, Ir, “Operasi Sistem Tenaga Listrik”, Balai Penerbit \& Humas ISTN, Bumi Srengseng Indah, Ps. Minggu, Jakarta Selatan.1990.

[6] Kurniawan, Y. "Loss Of Load Probability (Lolp) Index Untuk Menganalisis Keandalan Pembangkit Listrik". Journal Biastatistics | Departemen Statistika FMIPA Universitas Padjadjaran, 9(2), 2018

[7] Pillai N, Vijayamohanan. "Loss of Load Probability of a Power System". Journal of Fundamentals of Renewable Energy and Applications" 5. 1-9. 2015

[8] Hasan Fayazi Boroujeni, Meysam Eghtedari, Mostafa Abdollahi, Elahe Behzadipour. "Calculation of generation system reliability index: Loss of Load Probability ".Life Sci J. ;9(4):4903-4908, 2012

[9] Adibtyo Putro Gumilang, Rony Seto Wibowo, I Made Yulistya Negara, Penilaian Keandalan Sistem Tenaga Listrik Jawa Bagian Timur Dan Bali Menggunakan Formula Analitis Deduksi Dan Sensitivitas Analitis Dari Expected Energy Not Served. Jurnal Teknik ITS vol. 7, no. 1 (2018) 